\title{
Article
}

Arq Neuropsiquiatr 2011;69(3):470-474

\section{Evaluation of two Taenia solium cysticercal antigenic preparations (vesicular fluid and a glycoprotein fraction with affinity for lentil lectin) for the immunodiagnosis of neurocysticercosis by enzyme- linked immunosorbent assay (ELISA)}

\author{
Lisandra Akemi Suzuki, Cláudio Lúcio Rossi
}

\begin{abstract}
Objective: To evaluate the performance of two antigenic preparations (vesicular fluid - VF and a glycoprotein fraction, LLa-Gp fraction, purified from a whole parasite extract by lentil lectin affinity chromatography) from Taenia solium cysticerci for the immunodiagnosis of neurocysticercosis. Method: Fifty-six cerebrospinal fluid (CSF) samples (22 from patients with neurocysticercosis and 34 from patients with other neurological disorders) and 57 serum samples (22 from patients with neurocysticercosis, 18 from patients with other infections and 17 from presumably healthy persons) were assayed for anticysticercal IgG antibodies with an enzyme-linked immunosorbent assay (ELISA). Results: The VF ELISA showed $100 \%$ sensitivity and specificity in CSF and serum samples, whereas the sensitivity and specificity of the LLa-Gp ELISA were, respectively, $90.9 \%$ and $97.1 \%$, with the CSF samples and $95.5 \%$ and $100 \%$ with serum samples. There was no significant difference in the sensitivity and specificity of the two antigenic preparations used to screen CSF and serum samples. Conclusion: Considering the complexity and high cost of obtaining the LLa-Gp fraction, VF could be more suitable for screening specific antibodies by ELISA in CSF and serum samples from patients with neurocysticercosis.
\end{abstract}

Key words: antibodies, ELISA, neurocysticercosis.

Avaliação de duas preparações antigênicas de cisticercos de Taenia solium (líquido vesicular e uma fração glicoprotéica com afinidade para lentil lectina) para o imunodiagnóstico da neurocisticercose usando uma técnica imunoenzimática (ELISA)

\section{RESUMO}

\section{Correspondence}

Cláudio Lúcio Rossi

Departamento de Patologia Clínica Faculdade de Ciências Médicas Universidade Estadual de Campinas (UNICAMP) Rua Tessália Vieira de Camargo 126 13083-887 Campinas SP - Brasil

E-mail: clr@fcm.unicamp.br

\section{Support}

This research was supported by Fundação de Amparo à Pesquisa do Estado de São Paulo (FAPESP), Brazil

Received 30 September 2010

Accepted 4 February 2011
Objetivo: Avaliar o desempenho de duas preparações antigênicas (líquido vesicular LV e uma fração glicoprotéica, fração LL a-Gp, purificada do extrato total dos parasitas por cromatografia de afinidade com lentil lectina) de cisticercos de Taenia solium para o imunodiagnóstico da neurocisticercose. Método: Cinquenta e seis amostras de líquido cefalorraquidiano (LCR) (22 de pacientes com neurocisticercose e 34 de pacientes com outras doenças neurológicas) e 57 amostras de soro (22 de pacientes com neurocisticercose, 18 de pacientes com outras infecções e 17 de pessoas presumivelmente sadias) foram analisadas quanto à presença de anticorpos IgG anti-cisticercos com uma reação imunoenzimática (ELISA). Resultados: A reação ELISA LV apresentou 100\% de sensibilidade e especificidade em amostras de LCR e soro, enquanto a sensibilidade e a especificidade da reação ELISA LLa-Gp em amostras de LCR e soro foram de 90,9\% e

Department of Clinical Pathology, Faculty of Medical Sciences, State University of Campinas (UNICAMP), Campinas SP, Brazil. 
$97,1 \%$ e $95,5 \%$ e 100\%, respectivamente. Não foram encontradas diferenças significativas na sensibilidade e especificidade das duas preparações antigênicas utilizadas, tanto para amostras de LCR como para amostras de soro. Conclusão: Considerando a complexidade e o alto custo de obtenção da fração LLa-Gp, o LV pode ser mais adequado para a pesquisa de anticorpos específicos por ELISA em amostras de LCR e soro de pacientes com neurocisticercose.

Palavras-chave: anticorpos, ELISA, neurocisticercose.

Neurocysticercosis, a severe disease caused by larvae of the tapeworm Taenia solium in the human central nervous system, is a major public health problem in many developing countries in Latin America, Asia and Africa $^{1-3}$. This disease may cause a wide range of nonspecific neurological symptoms, with seizures, cysticercotic meningitis and intracranial hypertension being the most common clinical signs ${ }^{2,4}$. The heterogeneity of the clinical features associated with neurocysticercosis makes diagnosis of this disease very difficult when not combined with neuroimaging studies and epidemiological and laboratory data. Computed tomography and magnetic resonance are considered the gold standard for the diagnosis of neurocysticercosis, but their high cost is a limiting factor to the accessibility of these techniques in developing countries.

Immunological assays for the detection of specific anti-cysticercal antibodies in serum or cerebrospinal fluid (CSF) are a valuable tool in the diagnosis of neurocysticercosis. Crude extracts of whole T. solium or $T$. crassiceps cysticerci, crude extracts from particular components of the parasites (scolex, membrane or vesicular fluid), excretory-secretory products, purified antigens from crude extracts, recombinant proteins and synthetic peptides have been used in immunological tests to detect specific antibodies ${ }^{5-21}$. Currently, the most reliable immunological test available for the immunodiagnosis of neurocysticercosis is an enzyme-linked immunoelectrotransfer blot (EITB) assay based on glycoprotein antigens prepared by lentil lectin affinity chromatography from an extract of intact cysts ${ }^{6,16}$. However, enzyme-linked immunosorbent assays (ELISAs) are still extensively used to detect anti-cysticercal antibodies because of their simplicity and lower cost compared to EITB. Several studies have shown that ELISAs using vesicular fluid from T. solium and T. crassiceps have good diagnostic performance in terms of sensitivity and specificity ${ }^{5,7,11,15,17}$.

In this report, we describe results obtained by ELISA for the diagnosis of neurocysticercosis based on the use of vesicular fluid (VF) and a glycoprotein fraction, LLaGp fraction, purified by lentil lectin affinity chromatography from a crude extract of $T$. solium cysticerci as antigenic preparations.

\section{METHOD \\ CSF and serum samples}

The following serum and CSF samples were screened by ELISA for cysticercal-specific IgG: 22 serum and CSF samples collected concurrently from patients with neurocysticercosis, 34 CSF samples from patients with other neurological disorders (neurotoxoplasmosis, $n=4$; neurosyphilis, $\mathrm{n}=5$; neurocryptococosis, $\mathrm{n}=8$; multiple sclerosis, $\mathrm{n}=5$; viral meningitis, $\mathrm{n}=6$; bacterial meningitis, $\mathrm{n}=6$ ), 18 serum samples from patients with other infections (syphilis, $\mathrm{n}=5$; mononucleosis, $\mathrm{n}=3$; cytomegalovirus, $n=3$; hepatitis $A, n=2$, toxoplasmosis, $n=5$ ) and 17 serum samples from presumably healthy persons. The patients with neurocysticercosis had neuroimaging findings compatible with this disease, whereas the patients with other neurological disorders had no epidemiological and radiological evidence of neurocysticercosis. The patients with other infections and the presumably healthy persons had no clinical and epidemiological evidence of infection by T. solium. All patients were attended at the University Hospital of the State University of Campinas (Campinas, SP, Brazil). Our study was approved by the Ethics Committee of the School of Medical Sciences, UNICAMP, in accordance with the resolutions of the Brazilian National Ethics Committee.

\section{Cysticercal antigens}

Two antigenic preparations [vesicular fluid (VF) and a glycoprotein fraction, LLa-Gp fraction, purified from a whole parasite extract by lentil lectin affinity chromatography] were prepared from $T$. solium cysticerci obtained from a heavily infected, freshly slaughtered pig. VF was obtained as previously described ${ }^{17}$. Briefly, the parasites were ruptured individually in petri dishes using two needles and the VF released was collected with a Pasteur pipette and transferred to centrifuges tubes. The fluid was then centrifuged $\left(10,000 \times \mathrm{g}, 30 \mathrm{~min}, 4^{\circ} \mathrm{C}\right)$ and the supernatant sonicated for $1 \mathrm{~min}$ (two $30 \mathrm{~s}$ pulses with a 30s pause between pulses) in an ice bath using a Branson sonicator at a power setting of 3 with a $20 \%$ pulse duty cycle. Enzymatic inhibitors (phenylmethylsulfonyl fluoride - PMSF and leupeptin) were added to the sonicate at final concentrations of $5 \mathrm{mM}$ and $2.5 \mu \mathrm{M}$, respectively. 
The protein concentration was determined by the Bradford method ${ }^{22}$, after which the preparation was stored in aliquots at $-80^{\circ} \mathrm{C}$ until used.

The LLa-Gp fraction was obtained from a whole extract of T. solium cysticerci (WEC). The WEC was obtained as previously described ${ }^{15,17}$, with few modifications. Briefly, parasites maintained at $-80^{\circ} \mathrm{C}$ were thawed and resuspended in sterile $0.15 \mathrm{M}$ phosphate-buffered saline (PBS), pH 7.2 (1 volume of parasites to 3 volumes of PBS containing PMSF and leupeptin at the concentrations indicated above) and the material then homogenized in an ice-water bath using a Polytron homogenizer equipped with a PT-20 ST probe (three $30 \mathrm{~s}$ pulses at speed 3, with $30 \mathrm{~s}$ intervals between pulses). The homogenate was sonicated for $3 \mathrm{~min}$ ( $1 \mathrm{~min}$ sonication/ $1 \mathrm{~min}$ pause) in an ice-water bath using a Branson sonicator at power setting of 3 with a $20 \%$ pulse duty cycle. Protease inhibitors were added to the sonicate at the concentrations described above and the suspension was gently stirred for $2 \mathrm{~h}$ at $4{ }^{\circ} \mathrm{C}$ and then centrifuged $(20,000 \times \mathrm{g}$, $60 \mathrm{~min}, 4^{\circ} \mathrm{C}$ ). The supernatant (WEC) was carefully collected after removing the floating layer, filtered through $0.45 \mu \mathrm{m}$ filters and dialyzed against 0.15 M PBS, pH 8.0. After protein quantification (see above), the WEC was stored aliquots at $-80^{\circ} \mathrm{C}$ until used.

To obtain the LLa-Gp fraction, the material was thawed and applied to a Sepharose-4B-lentil-lectin column equilibrated with $0.15 \mathrm{M}$ PBS, $\mathrm{pH}$ 8.0, the column size being dependent on the amount of protein to be fractionated ( $1 \mathrm{ml}$ of resin was used for every $3 \mathrm{mg}$ of protein). The column was extensively washed with the equilibrating buffer and glycoproteins with affinity for lentil lectin were eluted with this buffer containing $0.2 \mathrm{M}$ $\alpha$-methylmannoside. The eluted fraction (LLa-Gp) was concentrated using a YM-10 membrane (Amicon Corporation, Beverly, MA, USA) and dialyzed against $0.15 \mathrm{M}$ PBS, pH 7.2. The protein concentration of LLa-Gp was determined and the material then stored in aliquots at $-80^{\circ} \mathrm{C}$ until used.

\section{Determination of the optimal reagent concentrations}

The ELISA procedure was standardized using excess amounts of all reagents except for that being tested. For antigen titration, increasing amounts of antigen (0.1 to $8.0 \mu \mathrm{g}$ protein $/ \mathrm{ml}$ ) were used. The optimal concentration of the conjugate (affinity-purified goat anti-human IgG labeled with peroxidase, Sigma-Aldrich, St. Louis, MO, USA) was based on titration experiments using human IgG-coated polystyrene ELISA plates.

\section{ELISA}

Cysticercal antigens were diluted to $4 \mu \mathrm{g}$ protein/ $\mathrm{ml}$ in $0.1 \mathrm{M}$ carbonate-bicarbonate buffer, $\mathrm{pH}$ 9.5, and used to sensitize the wells of U-bottomed ELISA plates (Greiner Bio-one, Kremsmünster, Austria). After sensitization for $1 \mathrm{~h}$ at room temperature and $14 \mathrm{~h}$ at $4^{\circ} \mathrm{C}$, the wells were washed once with PBS containing $0.1 \%(\mathrm{v} / \mathrm{v})$ Tween 20 (PBS-Tween) and $100 \mu \mathrm{l}$ of $0.1 \%$ bovine serum albumin (BSA) in PBS were added to the wells. Following a $30 \mathrm{~min}$ incubation at room temperature, the wells were washed twice with PBS-Tween and $100 \mu \mathrm{l}$ of each CSF or serum sample (diluted 1:5 and 1:75, respectively in PBSTween) were added to the wells for $1 \mathrm{~h}$ at room temperature. This incubation was followed by three washes with PBS-Tween and the addition of $100 \mu \mathrm{l}$ of the conjugate (diluted 1:800 in PBS-Tween) to each well. After incubation for $1 \mathrm{~h}$ at room temperature and three washes with PBS-Tween, $100 \mu \mathrm{l}$ of the substrate (tetramethylbenzidine-TMB $/ \mathrm{H}_{2} \mathrm{O}_{2}$ ) were added to the wells. Ten minutes after substrate addition, the reaction was stopped by adding $50 \mu \mathrm{l}$ of $2 \mathrm{~N} \mathrm{H}_{2} \mathrm{SO}_{4}$ to each well and the resulting absorbances were read at $450 \mathrm{~nm}$ using an ELISA reader (Multiskan MS, Labsystems, Finland). Positive and negative controls were included in each plate. Each CSF and serum sample was tested in duplicate with the two antigenic preparations in the same plate and the mean absorbance was determined. The final absorbance of each sample was determined by subtracting the mean absorbance of the two antigen controls in the corresponding plate. The cut-off value for the ELISA was determined using the highest $J$ index ${ }^{23}$, based on the formula: $J=$ $(a / b)+(c / d)-1$, where $a$ is the number of infected subjects with a positive ELISA, $b$ is the total number of subjects in the infected group, $\mathrm{c}$ is the number of uninfected subjects with a negative ELISA, and $d$ is the total number of subjects in the uninfected group.

\section{Data analysis}

The Cochran Q test was used to compare the sensitivities and specificities of the reactions ${ }^{24}$. Differences among results were considered significant when $\mathrm{p} \leq 0.05$.

\section{RESULTS}

Fifty-six CSF samples (22 from patients with neurocysticercosis and 34 from patients with other neurological disorders) and 57 serum samples (22 from patients with neurocysticercosis, 18 from patients with other infections and 17 from presumably healthy persons) were assayed for IgG using the two antigenic preparations (VF and LLa-Gp fraction).

The VF ELISA showed $100 \%$ sensitivity and specificity with the CSF and serum samples, whereas the sensitivity and specificity of the LLa-Gp ELISA with the CSF and serum samples were $90.9 \%$ and $97.1 \%$, and $95.5 \%$ and $100 \%$, respectively. One CSF sample from a patient with 
neurotoxoplasmosis cross-reacted with the LLa-Gp fraction. There was no significant difference in the sensitivities and specificities of the VF and LLa-GP ELISAs used to screen the CSF and serum samples.

\section{DISCUSSION}

Numerous studies have shown that glycoproteins from parasites are recognized as antigens by the human immune system. An EITB using glycoprotein antigens prepared by lentil lectin affinity chromatography from an extract of whole T. solium cysts ${ }^{6}$ has been considered the most reliable test for the immunodiagnosis of neurocysticercosis ${ }^{16,25}$. This test has an excellent specificity (>92\%). In contrast, there is marked variation (28\%-100\%) in the sensitivity of the test, depending on the number, location and maturation stage of the cysts in the $\mathrm{CNS}^{6,26-28}$. The major concerns for the use of this test in developing countries are its complexity, time of execution, and $\operatorname{cost}^{8,28}$.

With the exception of EITB, the performance of ELISAs is superior to other techniques used for the immunodiagnosis of neurocysticercosis. Several antigenic preparations of T. solium and T. crassiceps cysticerci have been used to detect anti-cysticercal antibodies. Several studies have shown that ELISAs standardized with the VF of T. solium or T. crassiceps cysticerci may be useful for the immmunodiagnosis of neurocysticercosis ${ }^{5,11,12,15,17}$. However, there is no agreement about the best antigenic preparation to use in ELISAs for neurocysticercosis.

Some reports have evaluated the use of glycoprotein antigens in ELISA for screening cysticercus-specific IgG. Plancarte et al. ${ }^{8}$ examined the usefulness of purified GP24 (a specific and highly antigenic glycoprotein antigen from $T$. solium cysts with affinity for lentil lectin) in ELISA and dot blot in 13 serum and 13 CSF samples from patients with neurocysticercosis, 3 CSF samples from patients with other neurological disorders, 3 serum samples from healthy individuals and 44 serum samples from patients with other parasite diseases. All serum and CSF samples from patients with neurocysticercosis were positive with ELISA and dot blot, whereas the three CSF samples from patients with other neurological disorders and the three serum samples from healthy individuals were negative by both techniques. All serum samples from patients with other parasite diseases were negative by dot blot. Prabhakaran et al. ${ }^{29}$ assessed the applicability of $T$. solium metacestode glycoproteins specific for lentil lectin as antigens in ELISA and immunoblot assays for diagnosing neurocysticercosis in Indian patients. In 107 patients with solitary cysticercus granuloma, the ELISA and immunoblot were positive in $80 \%$ and $62 \%$ of the cases, respectively, whereas in non-cysticercosis patients, the ELISA and immunoblot were negative in 94\% and $97 \%$ of the cases, respectively. Ishida et al. ${ }^{30}$ evaluated the performances of different cysticercal antigens ( $T$. solium cysticercal total saline, Tso; T. crassiceps cysticercal vesicular fluid, Tcra-vf and T. crassiceps cysticercal glycoproteins, Tcra-gp) for the immunodiagnosis of neurocysticercosis using ELISA and immunoblot. In 20 serum samples from patients with neurocysticercosis confirmed by neuroimaging studies, the ELISA done with Tso, Tcravf and Tcra-gp was positive in 19 (95\%), 18 (90\%) and 16 (80\%) patients, respectively. Among 53 serum samples from blood donors, three (5.6\%) gave positive results in ELISA using Tcra-vf. Twenty serum samples from patients with neurocysticercosis and 20 serum samples from blood donors were tested by immunoblot done with the Tcra-vf antigen. All serum samples from patients with neurocysticercosis were positive whereas all serum samples from blood donors were negative.

In the present study, we evaluated the usefulness of two antigenic preparations from T. solium cysticerci, i.e., vesicular fluid (VF) and a glycoprotein fraction (LLa-Gp fraction) purified from cysticercal extracts by affinity chromatography on a lentil lectin column, for the detection of specific anti-cysticercal IgG using ELISA. There was no significant difference in the sensitivity and specificity between the two antigenic preparations used to screen CSF and serum samples. One CSF sample from a patient with toxoplasmosis cross-reacted with the LLaGp fraction. Other studies have also shown that components of T. solium cysticerci are recognized by CSF and/ or serum samples from patients with toxoplasmosis ${ }^{17,31}$.

For routine diagnostic purposes, sensitive and specific antigen preparations must be available in cost-effective amounts. Considering the complexity and high cost of obtaining the LLa-Gp fraction, VF could be more suitable for detecting specific antibodies in CSF and serum samples of patients with neurocysticercosis.

\section{REFERENCES}

1. White AC Jr. Neurocysticercosis: updates on epidemiology, pathogenesis, diagnosis, and management. Annu Rev Med 2000;51:187-206.

2. Takayanagui OM, Leite JP. Neurocisticercose. Rev Soc Bras Med Trop 2001; 34:283-290.

3. Carpio A. Neurocysticercosis: an update. Lancet Infect Dis 2002;2: 751-762.

4. Garcia HH, Gonzalez AE, Tsang VC, Gilman RH. Neurocysticercosis: some of the essentials. Pract Neurol 2006;6:288-297.

5. Larralde C, Laclette JP, Owen CS, et al. Reliable serology of Taenia solium cysticercosis with antigens from cyst vesicular fluid: ELISA and hemagglutination tests. Am J Trop Med Hyg 1986;35: 965-973.

6. Tsang VC, Brand JA, Boyer AE. An enzyme-linked immunoelectrotransfer blot assay and glycoprotein antigens for diagnosing human cysticercosis (Taenia solium). J Infect Dis 1989;159:50-59.

7. Larralde C, Sotelo J, Montoya RM, et al. Immunodiagnosis of human cysticercosis in cerebrospinal fluid. Arch Pathol Lab Med 1990;114: 926-928.

8. Plancarte A, Fexas M, Flisser A. Reactivity in ELISA and dot blot of purified GP24, an immunodominant antigen of Taenia solium, for the diagnosis of human neurocysticercosis. Int J Parasitol 1994;24:733-738.

9. Garcia E, Ordoñez G, Sotelo J. Antigens from Taenia solium cysticerci used in complement fixation, enzyme-linked immunosorbent assay, and western blot (immunoblot) for diagnosis of neurocysticercosis. J Clin Microbiol 1995;33: 3324-3325. 
10. Ito A, Plancarte A, Ma L, et al. Novel antigens for neurocysticercosis: simple method for preparation and evaluation for serodiagnosis. Am J Trop Med Hyg 1998:59:291-294.

11. Bueno EC, Vaz AJ, Machado LR, Livramento JA. Neurocysticercosis: detection of $\lg G, \lg A$ and $\lg E$ antibodies in cerebrospinal fluid, serum and saliva samples by ELISA with Taenia solium and Taenia crassiceps antigens. Arq Neuropsiquiatr 2000;58: 18-24.

12. Pardini AX, Peralta RH, Vaz AJ, Machado LR, Peralta JM. Use of Taenia crassiceps cysticercus antigen preparations for detection of antibodies in cerebrospinal fluid samples from patients with neurocysticercosis (Taenia solium). Clin Diagn Lab Immunol 2002;9:190-193.

13. Peralta $\mathrm{RH}, \mathrm{Vaz}$ AJ, Pardini A, et al. Evaluation of an antigen from Taenia crassiceps cysticercus for the serodiagnosis of neurocysticercosis. Acta Trop 2002;83:159-168.

14. Villota GE, Gomez DI, Volcy M, et al. Similar diagnostic performance for neurocysticercosis of three glycoprotein preparations from Taenia solium metacestodes. Am J Trop Med Hyg 2003;68:276-280.

15. Arruda GC, da Silva AD, Quagliato EM, Maretti MA, Rossi CL. Evaluation of Taenia solium and Taenia crassiceps cysticercal antigens for the serodiagnosis of neurocysticercosis. Trop Med Int Health 2005;10:1005-1012.

16. Garcia HH, Del Brutto OH, Nash TE, White AC Jr, Tsang VC, Gilman RH. New concepts in the diagnosis and management of neurocysticercosis (Taenia solium). Am J Trop Med Hyg 2005;72:3-9.

17. Suzuki LA, Arruda GC, Quagliato EM, Rossi CL. Evaluation of Taenia solium and Taenia crassiceps cysticercal antigens for immunodiagnosis of neurocysticercosis using ELISA on cerebrospinal fluid samples. Rev Soc Bras Med Trop 2007:40:152-155.

18. Hell RC, Amin P, de Andrade HM, et al. Immunodiagnosis of human neurocysticercosis using a synthetic peptide selected by phage-display. Clin Immunol 2009;131:129-138.

19. Sahu PS, Parija SC, Narayan SK, Kumar D. Evaluation of an IgG-ELISA strategy using Taenia solium metacestode somatic and excretory-secretory antigens for diagnosis of neurocysticercosis revealing biological stage of the larvae. Acta Trop 2009;110:38-45.
20. Zimic M, Pajuelo M, Rueda D, et al. Utility of a protein fraction with cathepsin L-like activity purified from cysticercus fluid of Taenia solium in the diagnosis of human cysticercosis. Am J Trop Med Hyg 2009;80:964-970.

21. Deckers N, Dorny P. Immunodiagnosis of Taenia solium taeniosis / cysticercosis. Trends Parasitol 2010;26:137-144.

22. Bradford MM. A rapid and sensitive method for the quantitation of microgram quantities of protein utilizing the principle of protein-dye binding. Anal Biochem 1976;72:248-254.

23. Youden WJ. Index for rating diagnostic tests. Cancer 1950;3:32-35.

24. Fleiss JL. Statistical Methods for Rates and Proportions. In: John Wiley \& Sons Inc (Eds). 2 $2^{\text {nd }}$ edn, New York, NY, 1981.

25. Del Brutto OH, Rajshekhar V, White AC Jr, et al. Proposed diagnostic criteria for neurocysticercosis. Neurology 2001;57:177-183.

26. Wilson M, Bryan RT, Fried JA, et al. Clinical evaluation of the cysticercosis enzyme-linked immunoelectrotransfer blot in patients with neurocysticercosis. J Infect Dis 1991;164:1007-1009.

27. Aguilar-Rebolledo F, Meza-Lucas A, Torres J, et al. Evaluation of the enzymelinked immunoelectrotransfer blot assay for diagnosis of neurocysticercosis in children. J Child Neurol 2002;17:416-420.

28. Proaño-Narvaez JV, Meza-Lucas A, Mata-Ruiz O, García-Jerónimo RC, Correa D. Laboratory diagnosis of human neurocysticercosis: double-blind comparison of enzyme-linked immunosorbent assay and electroimmunotransfer blot assay. J Clin Microbiol 2002;40:2115-2118.

29. Prabhakaran V, Rajshekhar V, Murrell KD, Oommen A. Taenia solium metacestode glycoproteins as diagnostic antigens for solitary cysticercus granuloma in Indian patients. Trans R Soc Trop Med Hyg 2004;98:478-484.

30. Ishida MM, Peralta RH, Livramento JA, Hoshino-Shimizu S, Peralta JM, Vaz AJ. Serodiagnosis of neurocysticercosis in patients with epileptic seizure using ELISA and immunoblot assay. Rev Inst Med Trop São Paulo 2006;48:343-346.

31. da Silva AD, Quagliato EM, Rossi CL. A quantitative enzyme-linked immunosorbent assay (ELISA) for the immunodiagnosis of neurocysticercosis using a purified fraction from Taenia solium cysticerci. Diagn Microbiol Infect Dis 2000;37:87-92. 